\title{
Comparison of Energyplus Simulation Results of Double Skin Façade System with CFD and Experiment Data
}

\author{
Junghyon Mun ${ }^{1}$, Jongik Lee ${ }^{1}$, Brian Baewon Koh ${ }^{1}$ \\ ${ }^{1}$ R\&D Center of Sun\&Light, Seoul, Republic of Korea
}

\begin{abstract}
The purpose of this paper is to make a building simulation model for the double skin façade system using Energyplus and optimize the model using $\mathrm{CFD}$ (Computational Fluid Dynamics) and experimental data. When conducting the double skin façade simulation using Energyplus, it is required to select a proper solar distribution model which allows the beam solar radiation to be transmitted into the adjacent zone correctly. In addition, interzone heat and air transfer between the cavity space of the double skin façade system and the adjacent living space should be modelled correctly. Discharge coefficient calculation is an important process in making a building simulation when windows of the double skin façade system open. Discharge coefficient can be determined using experimental data but if the experiment data are not sufficient enough, CFD analysis can be used to get the coefficients. The wind pressure coefficients can also be obtained using CFD.
\end{abstract}

\section{Introduction}

In south Korea, there are more than 3.3 million of apartment units which were built more than 20 years ago. The thermal performance of those apartments is relatively pool against currently built apartments. Therefore, the old apartments are a subject of remodelling to reduce energy consumption in building energy sector. One of the major remodelling measures is to replace the old window systems with the high performance and air tight window systems. Currently, a lot of researches have been carried out to develop high performance window systems by laboratories and universities in South Korea. iSEUM (Integrated Smart Envelope Unit Module) is one of the results from those researches. It is a multi-functional double skin façade system which is integrated with energy equipment and control systems such as a photovoltaic system and an energy storage system to save the building energy.

The purpose of this paper is to build an energy simulation model of a double skin façade system and calibrate the model using computational fluid dynamics (CFD) and experimental data. The best way to calibrate the energy simulation model is to use experimental data. In this case, long-term monitoring data are needed. Instead of using long term monitoring data, CFD analysis was used to assist calibrating process of the energy simulation model using one day short term monitoring data.

In this paper, energy simulation results were compared with the experimental data and CFD results. In the process of comparing the results each other, the limitations of energy simulation for double skin façade modelling was investigated and the method to overcome the limitation using CFD analysis was suggested.

\section{Experiment Set-up}

An experiment was conducted using the first prototype of iSEUM located in Daejeon, South Korea and the prototype is seen in Figure 1. The height of the prototype is $2.460 \mathrm{~m}$ and the width is $6.439 \mathrm{~m}$. The detailed dimensions of the test facility are seen in Figure 2.

The depth of the cavity space is $0.742 \mathrm{~m}$ and a $0.404 \mathrm{~m}$ deep overhang attaches to the front facade. In general, a double skin façade system has shading devices such as a venetian blind to control the solar irradiance. However, iSEUM uses an overhang instead of blind systems.

There are three types of windows used in the prototype. They are Fixed windows, sliding windows and project windows. They use the same glazing system, which is an argon filled low-E double glazing (5mm soft low-E glass $+14 \mathrm{~mm}$ argon gas $+5 \mathrm{~mm}$ clear glass). The frame material of the windows is aluminium. The construction material of the iSEUM prototype is described in Table 1.

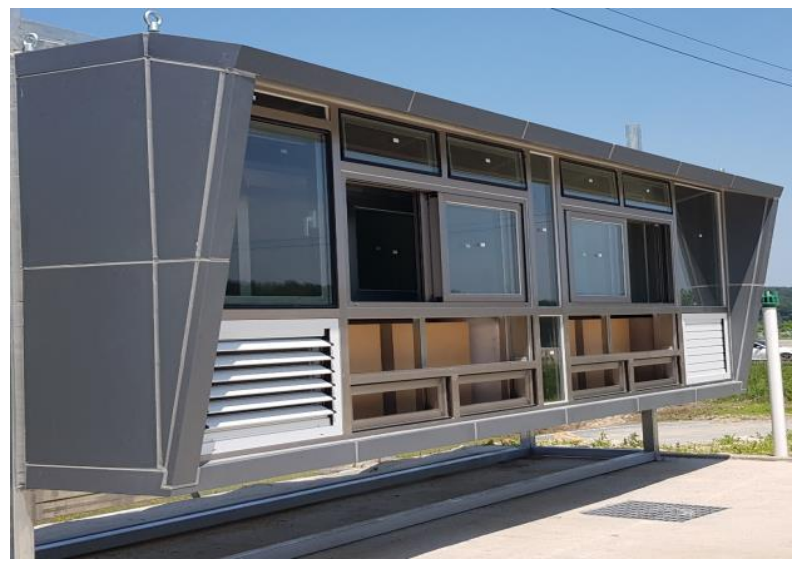

Figure 1: Prototype of iSEUM. 
The U-value of each window type was measured by a state authorized test facility. SHGC (Solar heat gain coefficient) and VT (Visible light transmitted) of the glazing system were obtained from manufacturer data.

In this experiment, air temperature, air velocity, air humidity and solar radiation were measured. The solar radiations were measured on the horizontal roof surface and the tilted overhang surface. The solar radiation data were used to predict electricity generation by photovoltaic panels and to make a local weather file of the experimental site. The surface temperatures were measured on the inner and outer surfaces of frames, inner glazing and outer glazing. The overhang surface temperature was also measured to predict the PV performance variations with surface temperature data. The cavity air temperatures were measured at $0.2 \mathrm{~m}, 1 \mathrm{~m}$, $1.5 \mathrm{~m}, 2 \mathrm{~m}$ height to investigate the air temperature variation with solar radiation. The air velocities at upper project window and the lower project window were measured. The air velocity data were compared with CFD and energy simulation results. Relative humidity in the cavity was measured in the center of the space to calculate the air property with air temperature data.

A weather station was installed on the top of the prototype and it measured wind direction, average wind speed, maximum wind speed, rain state, ambient temperature, ambient humidity and barometric pressure of the site. The data measured by the weather station were used to make a local weather file for energy simulation. Figure 3 shows the measured parameters and the measuring points in the prototype.

Table 1: iSEUM prototype construction material.

\begin{tabular}{|c|c|c|c|c|}
\hline \multirow{2}{*}{ Surface } & \multicolumn{4}{|c|}{$\begin{array}{c}\text { Material (thickness, mm) } \\
\text { (from outer layer to inner layer) }\end{array}$} \\
\hline \multirow{2}{*}{ Side wall } & $\begin{array}{c}\text { OSB } \\
\text { board } \\
(11.5)\end{array}$ & $\begin{array}{c}\text { R-12 } \\
\text { insulation }\end{array}$ & $\begin{array}{c}\text { OSB } \\
\text { board } \\
(11.5)\end{array}$ & \\
\hline $\begin{array}{c}\text { Roof/ } \\
\text { floor }\end{array}$ & $\begin{array}{c}\text { OSB } \\
\text { board } \\
(11.5)\end{array}$ & $\begin{array}{c}\text { air gap } \\
(5)\end{array}$ & $\begin{array}{c}\text { R-12 } \\
\text { insulation }\end{array}$ & $\begin{array}{c}\text { OSB } \\
\text { board } \\
(10)\end{array}$ \\
\hline
\end{tabular}
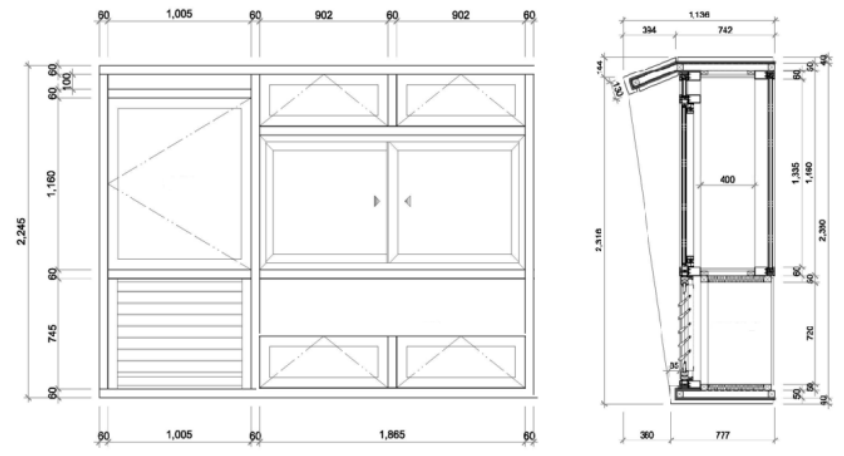

Figure 2: Elevation and section of experimental space the prototype.
The major experimental condition is open/close state of the upper and lower project windows of the double skin façade system. In the study, the first set of experiments were carried out to measure air velocity and temperature profiles of the cavity when the upper and lower project window were closed. The second set of experiments were carried out to measure the air temperature and velocity in the cavity and at the upper and the lower project windows when the upper and the lower project windows were opened.

\section{Simulation Process}

\section{Building energy simulation process}

There are many researches using energy simulation to predict thermal performance of double skin façade systems. N.Hamza(2005) and Chan et al(2009) showed the advantage of double skin façade system to reduce cooling load using energy simulation. On the other hand, Gratia et al $(2004,2007)$ suggested the results that the double skin facade system increases cooling load in their research. The existing studies showed different result for availability of the double skin façade system to reduce cooling and heating load.

D .Kim (2011) revealed the limitation of energy simulation for prediction of the temperature profile in the cavity space. He compared the simulation results and monitoring data to show uncertainty of prediction of surface temperature of the cavity using the energy simulation. In the study, he pointed out the cause of errors are uncertainty of simulation input data such as convection coefficients, leakage area, and wind pressure coefficients compared with the actual test facility.

In this study, Energyplus 8.7 was used to make a simulation model which is a whole building energy simulation software and developed by Department of Energy. There are five solar distribution models in Energyplus. They are "Minimal Shadowing", "Full Exterior", "Full Interior and Exterior", "Full Exterior with Reflections", and "Full Interior and Exterior with Reflections" (EnergyPlus input/output reference, 2018).

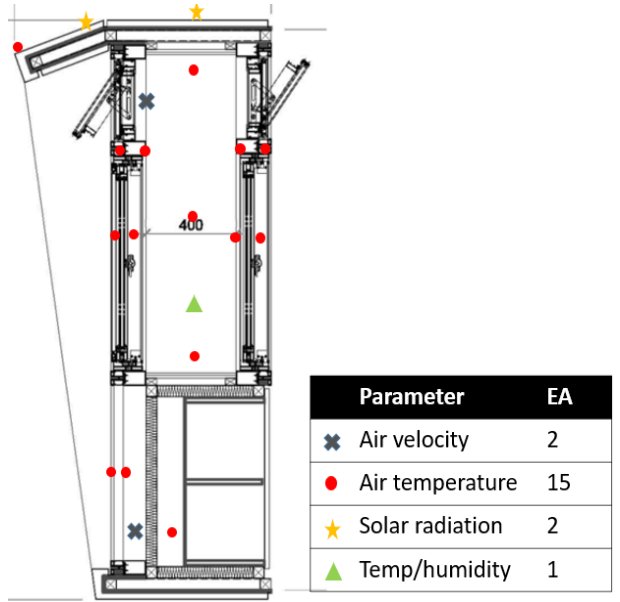

Figure 3: Measured points and parameters. 
A solar distribution model determines how beam solar radiation and reflectance from exterior and interior surfaces are calculated. If "Minimal Shadowing" or "Full Exterior" or "Full Exterior with Reflections" is selected, all beam solar radiation entering the zone is assumed to hit the floor and the reflected radiation by the floor is assumed to be added to the transmitted diffuse radiation and uniformly distributed on all interior surfaces. It means that beam solar radiation directly transmitted into the living space through the inner glazing of the cavity space is ignored.

If "Full Interior And Exterior" or "Full Interior And Exterior with Reflections" is selected, the program calculates the amount of beam radiation falling on each surface in the zone, including floor, walls and windows and the beam solar radiation through the inner glazing of the double skin façade system can be properly calculated. It is important to make sure that the double skin facade is modelled to be a convex and enclosed space. If double skin façade system is not a convex or enclosed space, "Full Interior And Exterior" or "Full Interior And Exterior With Reflections" option cannot be selected and it is impossible to calculate how much beam solar radiation is transmitted into the zone next to double skin facade zone. Therefore, it should be checked whether the space is modeled to be an enclosed and convex space and whether the solar radiation option is chosen to be "Full Interior And Exterior" or "Full Interior And Exterior with Reflections" in Energyplus.

To analyse airflow in the cavity space, air flow network model was used in Energyplus. The air flow network model enables to calculate multizone airflows by wind and surface leakage. In addition, the temperature and humidity of selected locations can be calculated using the air flow network model.

The cavity space is divided into two spaces and the center of each space is defined a node. There are five external nodes defined in this model. 3 external nodes are defined for the north outdoor space, the east outdoor space, and the west outdoor space of iSEUM. Two external nodes are defined in the south outdoor spaces of $1 \mathrm{~m}$ height and $3 \mathrm{~m}$ height as seen in figure 4. A lower cavity node is connected to the lower external south space node and the upper cavity node. The upper cavity node is connected to the upper external south space node and an adjacent zone (living room) node and the lower cavity node.

The air flow network model calculates the pressure difference, the air flow velocity and the air flow rate between two connected nodes. Node temperature and node humidity level are also calculated in Energyplus.

To calculate the pressure difference between an outdoor node and an interior node, wind speed, wind direction and wind pressure coefficient $(\mathrm{Cp})$ data of the outdoor space are required. The wind speed and wind direction data were measured through experiments. The wind pressure coefficients can be obtained using CFD.

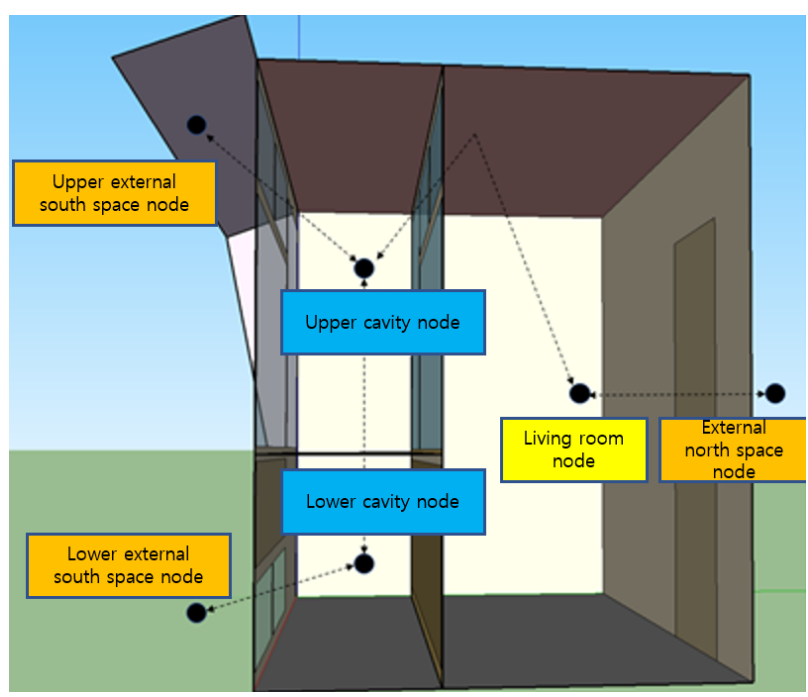

Figure 4: Air flow network setup.

After getting the pressure difference between two connected nodes, the air flow and air velocity between two nodes is calculated. In this process, the discharge coefficients for each opening are required. The discharge coefficient is related to the hydraulic resistance of airflow network (1998, F. Flourentzou,). The generally used discharged coefficient $(\mathrm{Cd})$ is $0.6 \pm 0.2$ and the default value used in Energyplus is 0.6 when a vertical door/window is opened and 0.5 when it is closed. The discharge coefficients can be calculated using air flow rate through an opening and the air flow rates were calculated using CFD analysis.

The weather file of the experiment site, Daejeon, South Korea was developed using the measured data and the existing weather file. The weather file editing program, Elements 1.06, was used to generate the local weather file.

The problem with generating a local weather file is to extract solar radiation parameters. The measured solar radiation data are about horizontal solar radiation. The direct solar irradiance and diffuse solar irradiance data were not measured independently. Therefore, the solar decomposition was required to extract those data from the measured horizontal solar radiation data. Actually, the proper solar decomposition model for the experimental site could not be found. Instead of using solar decomposition, the same days as the experiment date for which the cloud level is 0 were chosen and the weather data of the days were edited. In this process, the air temperature, air humidity, wind direction, wind velocity and rain indication data of one day were replaced with the measured data and the solar radiation data were not changed. Under this condition, the final local weather file is generated for 1 day of September. The local weather file is used for calibration of CFD and energy simulation models.

\section{CFD modelling process}

CFD has been used for analysing the double skin façade system for design optimization and investigating the 
accurate modelling techniques. A. papas et al(2008) investigate the correlation among double skin façade system design parameters. He suggested the CFD modelling process for air flow driven by buoyancy effect and validated the process. He used RNG k- $\varepsilon$ and Boussinesq model in his study and the difference between experiment and CFD result was $9 \%$ for air flow prediction and $15 \%$ for air temperature prediction. M. Montiel et a 1 (2013) revealed the effectiveness of Boussinesq model for heat transfer analysis for open space using CFD. D. Angelo showed the necessity of simplification of CFD modelling for the double skin façade system in the study. Simplified CFD model was compared with experiment and the reliability of simplification process was studied. W. Pasut et al evaluated various CFD models to find the optimal CFD model for making analysis of the double skin facade system. In the study, RNG k- $\varepsilon$ model was recommended to obtain reliable CFD result.

In this study, the geometry was drawn using Autocad and it was imported to CFD program (Star CCM). The model geometry is seen in Figure 5. The generally used three turbulent models, Standard $\mathrm{k}-\varepsilon$ and Realizable k- $\varepsilon$ Standard k- $\omega$ were compared with experimental data to find the most suitable model. The input data for each case study is seen in table 2 .

In the input process, the turbulence intensity was set $10 \%$ for all three models and the governing equations was selected to be Reynolds-Averaged Navier-Stokes. With different turbulent models, the airflow prediction and temperature prediction results show different values.

The solar radiation model was set to be Solar load which calculates the horizontal solar irradiance using latitude, longitude values of the site with time. For buoyance model, Boussinesq model was chosen. Under those condition, CFD analysis was carried out and the results were compared with experimental data. The window optical and thermal properties were tested by a state authorized test facility and the data were used as boundary condition of the model. Other boundary conditions were set to be adiabatic.
The comparison result among three turbulent models is seen in Figure 6 and 7. From the results of three case studies, it was observed that air entering through the lower project window moved to the upper space due to buoyancy driven by solar radiation and the air density change.
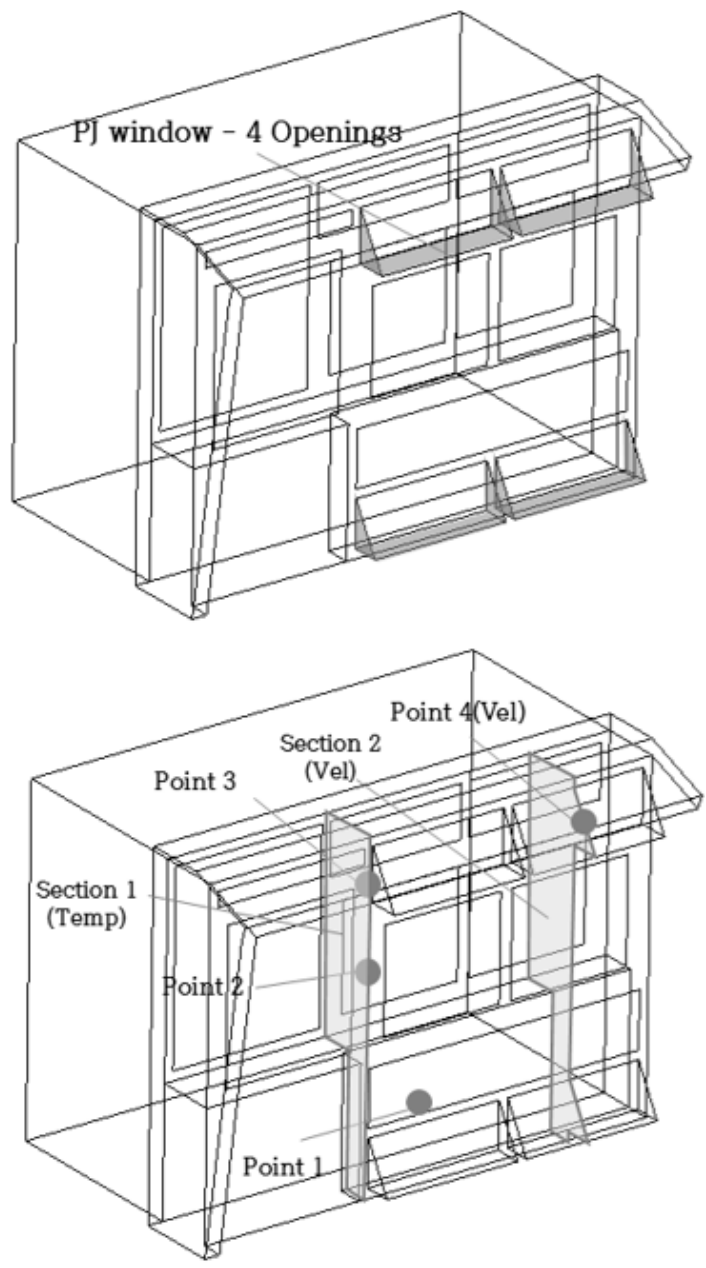

Figure 5: CFD geometry model image.

Table 2: CFD mesh and physics model.

\begin{tabular}{|c|c|c|c|}
\hline Mesh \& Physics model & Case1 & Case2 & Case3 \\
\hline Turbulence model & Standard k- $\varepsilon$ & Rearlizable k- $\varepsilon$ & Standard k- $\omega$ \\
\hline Turbulence intensity & \multicolumn{3}{|c|}{$10 \%$} \\
\hline Governing equation & \multicolumn{3}{|c|}{ Reynolds-Averaged Navier-Stokes } \\
\hline Wall Treatment & \multicolumn{3}{|c|}{ Two-Layer All y+ Wall Treatment } \\
\hline Air properties & \multicolumn{3}{|c|}{ gas } \\
\hline Buoyancy method & \multicolumn{3}{|c|}{ Boussinesq model (Thermal Expansion Coefficient $0.0033 / \mathrm{K}$ ) } \\
\hline Radiation (solar load) & \multicolumn{3}{|c|}{$\begin{array}{l}\text { 2018. 08. } 18 \text { 13:00 using experiment data } \\
\text { latitude } 36.31^{\circ} \text {, longitude } 127.30^{\circ} \text { (South Korea local) }\end{array}$} \\
\hline State & \multicolumn{3}{|c|}{ Steady } \\
\hline $\begin{array}{l}\text { Number of cells } \\
\text { (Mesh shape) }\end{array}$ & \multicolumn{3}{|c|}{$\begin{array}{c}450,000 \text { Cells } \\
\text { (Trimmed mesh) }\end{array}$} \\
\hline
\end{tabular}


In the case 1 result, the vortex was observed in the upper space and the maximum flow velocity was $0.202 \mathrm{~m} / \mathrm{s}$. In the case 2 result, the vortex did not occur and the acceleration of air flow was observed in the upper space. The maximum air velocity was $0.2 \mathrm{~m} / \mathrm{s}$. The case 3 result shows multiple vortex in the cavity space and the maximum air velocity was $0.4 \mathrm{~m} / \mathrm{s}$. Figure 8 show the comparison between the CFD results and experimental data at 4 different heights. As seen in Figure 8, the result using Realizable k-e model shows most similar temperature profile with experimental data. The air temperature value by CFD was overestimated and the reason is that the infiltration through cracks was ignored in this calculation.

\section{Result and Discussion}

Double skin facade system shows different thermal behaviours according to the window open/close states. When all windows are closed, the double skin façade system gives additional thermal resistance to the building like usual double or triple window systems. When the

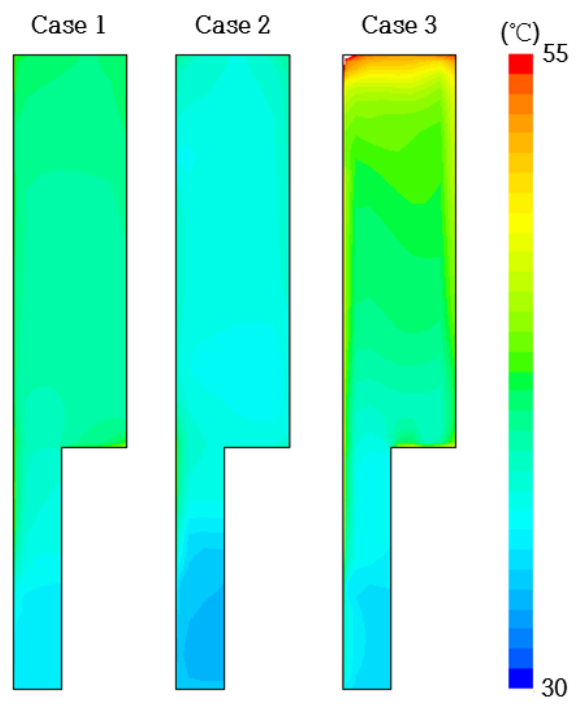

Figure 6: Turbulent model case study section1 images. (Temperature)

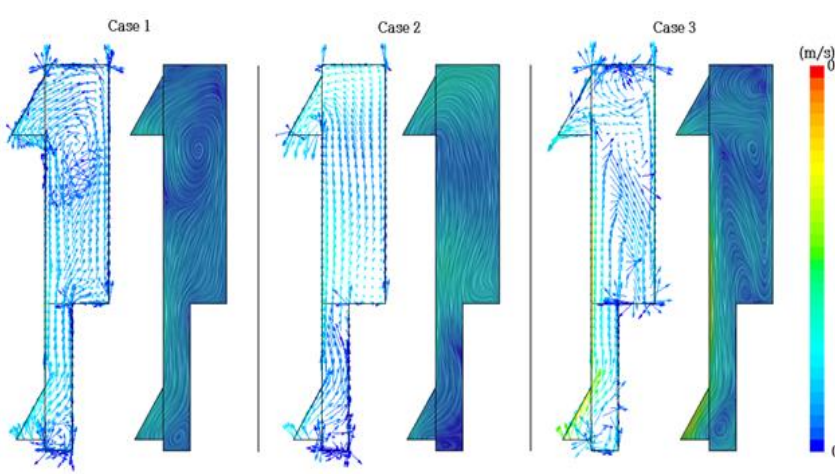

Figure 7: Turbulent model case study section2 images. (velocity) windows in the double skin façade system are opened, the heated air by solar radiation in the cavity space can lead to the living space to reduce or increase heating and cooling load. In this study, the window all open condition and the project widows open condition in outer layer of the double skin façade systems were simulated separately using Energyplus to predict thermal performance of iSEUM prototype.

\section{Project windows all closed condition}

When all windows close in the double skin façade system, the thermal movement through the double skin facades is similar to an attached green house. It provides high insulation to the building envelope which the double skin façade system is installed on. In addition, the air in the cavity space provides additional heat to the living space by conduction through the inner layer of the double skin façade system. General energy simulation programs can only analyse these two thermal performances. However, there is another thermal movement related to double skin facades system. It is heat transfer driven by airflow between the cavity space and the living space, which is analysed using Airflow network model in Energyplus.

In using Airflow network in Energyplus, the first step is to calculate pressure at each node. The wind pressure is calculated by Bernoulli's equation seen below.

$$
P_{w}=C_{p} \rho \frac{V_{r e f}^{2}}{2}
$$

where, $\mathrm{Pw}$ is the wind surface pressure relative to static pressure in undisturbed flow $(\mathrm{Pa})$ and $\rho$ is the air density $(\mathrm{kg} / \mathrm{m} 3) . \mathrm{V}_{\text {ref }}$ is the reference wind speed at local height $(\mathrm{m} / \mathrm{s})$ and $\mathrm{Cp}$ is the wind surface pressure coefficient.

The role of CFD in this case study is to calculate the wind pressure coefficients which is dependent on the shape of the building and wind directions. Figure 9 shows the wind pressure coefficient set for the south face of the prototype.

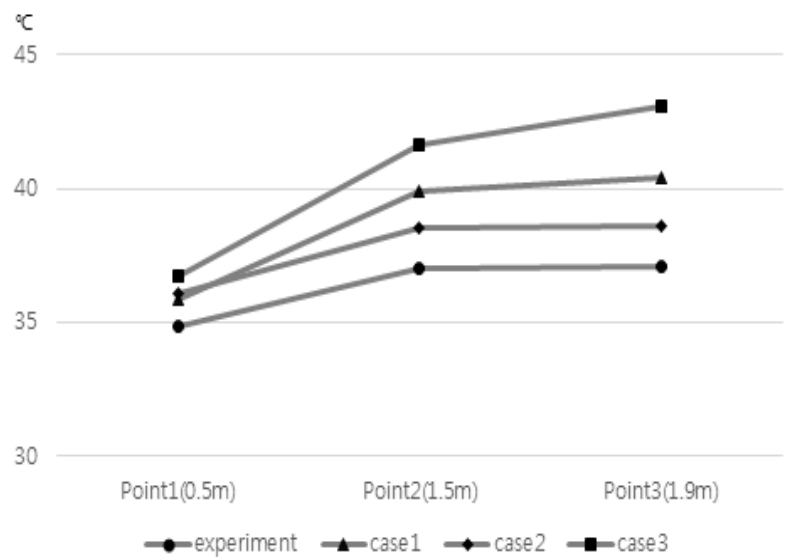

Figure 8: Comparison of between CFD results and experimental data. 


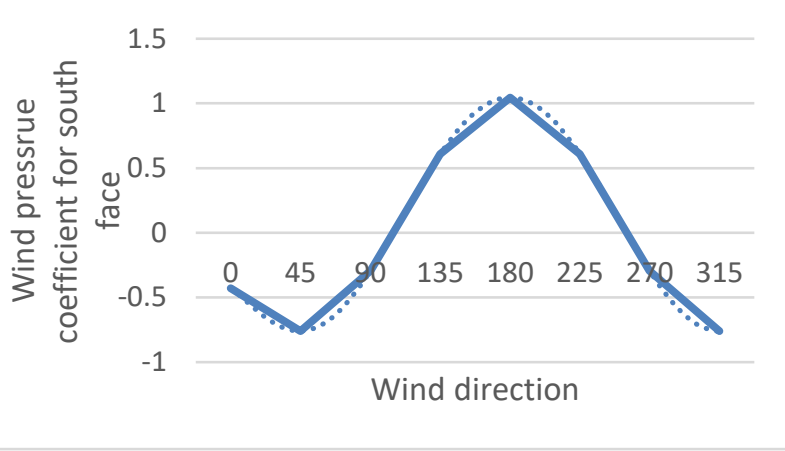

Figure 9: The wind pressure coefficient calculated using CFD for iSEUM prototype.

For calibration of the simulation model, the air temperature data which were calculated using Energyplus were compared with experimental data. The simulation input data were adjusted to make the simulation output match the experimental data. The target of the calibration is to match the average temperature difference between the experiment and the simulation less than 2 degree Celsius.

Figure 10 shows the calibration result. As seen in the figure, the hourly temperature profiles are very similar between experiment and simulation and the average temperature difference is less than 2 degree Celsius.

Using the calibrated model, the airflow through inner window of the iSEUM prototype from the cavity space when the wind speed is varied. Using "Ideal load air system model" in Energyplus, monthly heating load for January in Daejeon, Korea is calculated when the average wind speed is varied. At the same time, heat loss of the living space (Interzone Air Transfer Heat Removal) by air flow from/to the cavity space and infiltration heat loss (Infiltration Heat Removal) and conduction heat loss (Conduction Heat Removal) of the living space were calculated and compared each other when the average wind speed was varied from $1 \mathrm{~m} / \mathrm{s}$ to $5 \mathrm{~m} / \mathrm{s}$.
In this experimental space, iSEUM is installed on the south wall and a door is installed on the north wall. The infiltration occurs through the north door. The interzone air transfer heat removal occurs through iSEUM which is installed on the south wall

The living room air temperature is maintained to be $20^{\circ}$ C. Therefore, the cavity air temperature is lower than the living room temperature during the simulation period (January). As interzone air flow increases, the interzone heat loss increases too.

Figure11 shows the simulation results when the wind speed changes and reveals importance of the interzone airflow calculation for modeling double skin façade systems. The living space of the experimental space is made of sandwich panels of which thermal resistance is $0.75 \mathrm{~m}^{2} \mathrm{~K} / \mathrm{W}$. The conduction thermal loss is dominant for the building. However, as the wind speed increases, the importance of air and heat transfer through the envelopes increases. As seen in Figure 11, interzone airflow calculation is critical for making a building simulation model for the double skin façade. Without the interzone airflow calculation, an energy simulation program cannot simulate the double skin façade system properly.

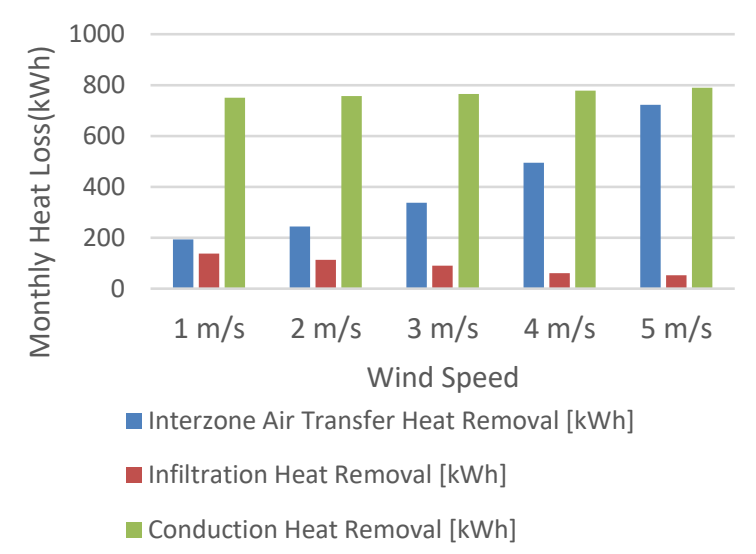

Figure 10: Comparison of monthly building heat loss component when the wind speed changes.

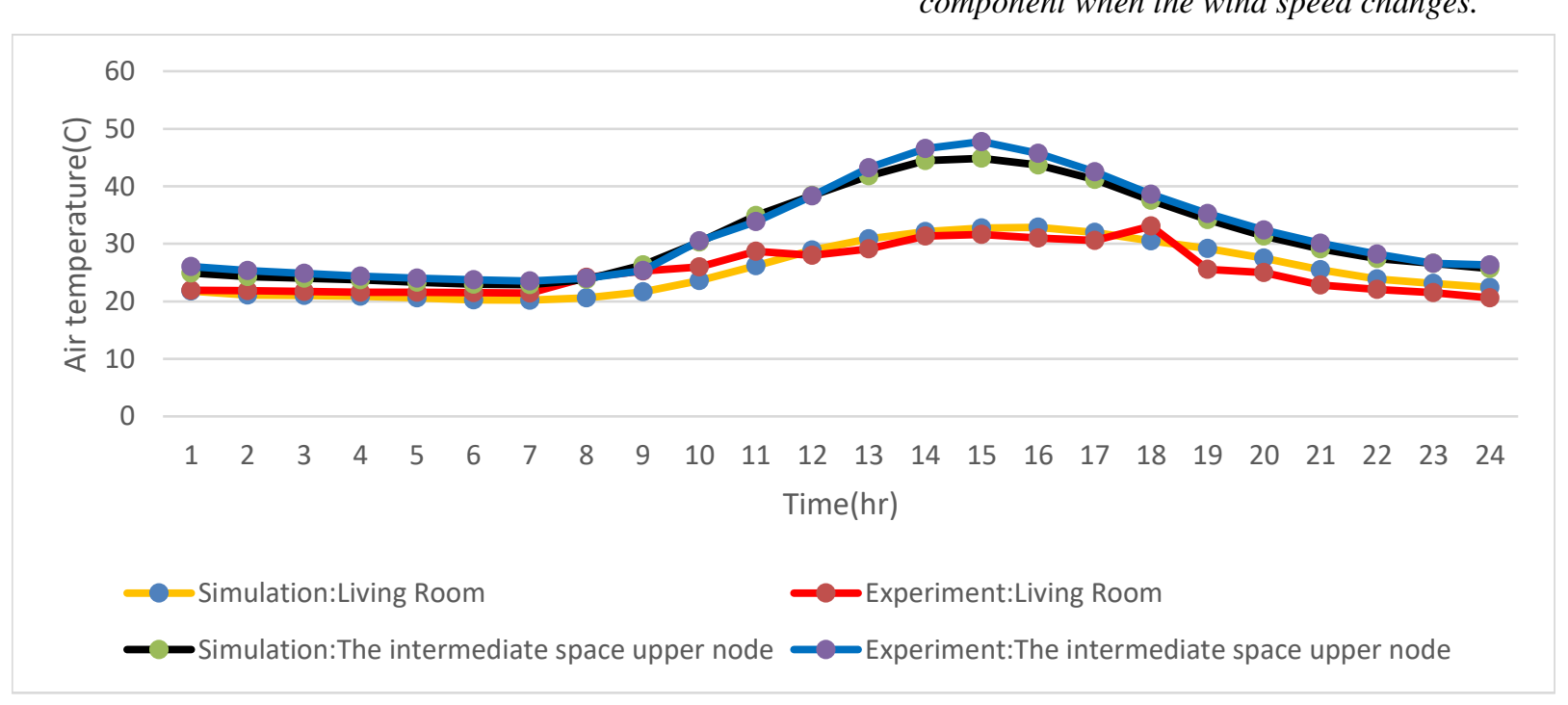

Figure 11: Comparison of temperature between simulation and experiment. 


\section{Project widows open condition in outer layer of iSEUM}

The project windows in the double skin façade system can be operated by a user to reduce thermal load. In this study, cooling season operation is only considered. It means the project windows located on the outer layer open to exhaust the cavity air heated by the solar radiation. It is because the cooling load increases if the heated air in the cavity space is transferred into the living space in the cooling season. Therefore, the heated air in the cavity space should be exhausted through upper project windows. Due to the buoyancy effect, the heated air moves upward and the empty space is filled with the air entering though the lower project windows. Therefore, the upper project windows and lower project windows open together in the cooling season to exhaust the heated air from the cavity space.

Figure 12 shows the comparison of air velocity between the measured data and the energy simulation data during the day. In energy simulation, the airflow network was set to be the default values used in the example files. The discharge coefficients for windows are set to be 0.6 and the air mass flow exponent was set to be 0.65 . The effective leakage area was calculated with the opening area of the project windows. As seen in the next graph, the air velocity calculated at the upper project window by simulation is around the half of the measured values. At the lower project windows, the difference between the simulation and the experiment is smaller than that at the upper project window. It is because the temperature variation at lower zone is smaller than the upper zone where the solar radiation is transmitted directly and the temperature variation is much bigger than the lower zone.
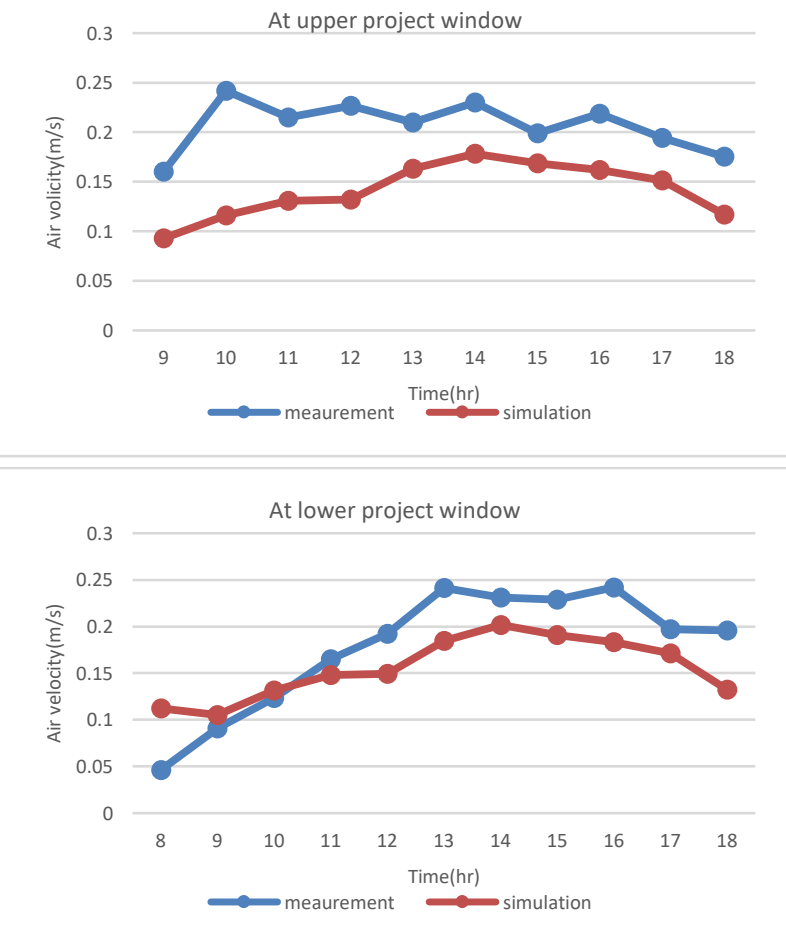

Figure 12: Comparison of air flow between the energy simulation using default setting and the experiment.
In this study, the cavity space in iSEUM is divided into 2 zones and the air movement driven by buoyancy was investigated using Airflow network in Energyplus. There is limitation in this approach. Actually, there is considerable temperature difference between top and bottom locations. However, Energyplus cannot estimate accurately the temperature variation of air and window surface in the double skin façade system. It only gives the average temperature values in each zone. For overcoming this problem, CFD analysis is adopted in this study. Using CFD analysis, it is possible to obtain temperature and air flow variation within the double skin facade system in detail. It makes possible to get accurate coefficients of airflow network in energy simulation to get more reliable results.

F.Flourntzou(1997) suggested methods to calculate the discharge coefficient from experimental data and it is shown in equation (2)

$$
\mathrm{Cd}=\frac{v}{A \sqrt{2 g\left(z-z_{N P L}\right) \frac{\Delta T}{T}}}
$$

where, $\mathrm{Cd}$ is the discharge coefficient and $\mathrm{v}$ is the measured air velocity $(\mathrm{m} / \mathrm{s}) . \Delta T$ is the temperature difference between opening inside and outside and $\mathrm{T}$ is the ambient temperature $\left({ }^{\circ} \mathrm{C}\right) . \mathrm{Z}$ is the opening height and $Z_{N P L}$ is the neutral pressure level height $(\mathrm{m})$. A is the opening area $\left(\mathrm{m}^{2}\right)$ and $\mathrm{g}$ is the gravitational constant $\left(\mathrm{m} / \mathrm{s}^{2}\right)$.

In this study, CFD analysis results were used to estimate the discharge coefficient (Cd) instead of experimental data. All variables to calculate the discharge coefficient (Cd) were obtained from CFD. The best option is to use experimental result but the experiment result has limitation to get the all parameters correctly for using equation (2). Therefore, the experimental data is used to calibrate the CFD simulation model and the parameters obtained from CFD analysis were used to calculation the discharged coefficient (Cd) using equation (2). The calculated discharged coefficient was 0.65 . Using the calculated discharge coefficient, the air flow at upper and lower project windows were calculated again with Energyplus. The result for air flow at upper project window is seen in figure 13. As seen in the figure the difference between the new simulation result and experiment is within $10 \%$.

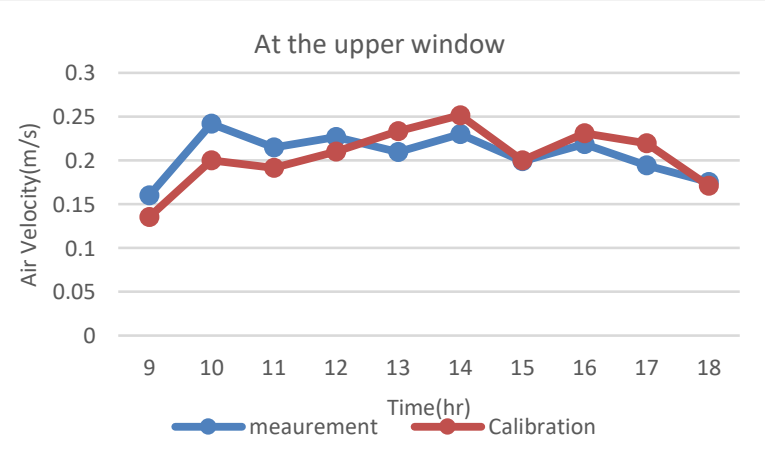

Figure 13: Comparison of air velocity simulation result after calibration with experiment data. 


\section{Conclusion}

In this study, it was investigated what is the proper energy modelling process for the double skin facade system and how to use CFD result for getting better energy simulation result.

In this paper, the double skin façade system modelling was performed according to the states of window open/close conditions. When conducting energy simulation of the double skin façade system using Energyplus, it is important to set the correct solar distribution option and make sure that the selected solar distribution model allows the beam to be transmitted into the adjacent zone correctly. In Energyplus, "Full Interior And Exterior" option should be selected in the solar distribution section. For infiltration setting, it should be check interzone heat and air transfer between the cavity space of the double skin façade system and the living space. For modelling window open condition, proper decision of discharge coefficient value is one of the core processes in calibration process. It can be carried out using experimental data but if the experiment data is not sufficient enough, CFD analysis can be used to get the coefficients.

\section{Acknowledgement}

This work was supported by the Korea Institute of Energy

Technology Evaluation and Planning (KETEP) and the Ministry of Trade, Industry \& Energy (MOTIE) of the Republic of Korea (No. 20172010000370)

\section{References}

Jang, M. K., Kim, S. M., Song, I. H., Lee, H. J. (2016) The energy saving effect of existing buildings according to the green remodeling. Proceedings from SAREK 2016: The Society of Air-conditioning and Refrigerating Engineers of Korea. Seoul(South Korea), 25 November 2016.

Diego, A., Alessanro, D. (2015) Modeling natural ventilation in double skin façade. Proceedings from IBPC2015: 6th International Building Physics Conference. Torino(Italy), 14-17 June 2015.

Montiel Gonzalez, M., Hinojosa Palafox, J., Estrada Gasca, C. (2013) Numerical study of the Boussinesq approach velidity for natural convection and surface thermal radiation in an open cavity. Revista Mexicana de Fisica 59, 594-605

N. Hamza. (2005) Double versus single sknin façade in hot arid areas. Energy and Buildings 37(6), 536-572.

Chan, A.L.S., Chow, T.T., Fong, K.F., Lin, Z., (2009) Investigation on energy performance of double sin façade in Hong Kong. Energy and Buildings 41(11), 1135-1142.

Gratia, K., Herde, A.D. (2004) Optimal operation of a south double-skin façade. Energy and Buildings 36(1),41-60.
Gratia, K., Herde, A.D., (2007) Are energy consumptions decreased with the additon of a bould-skin. Energy and Buildings 39(5), 605-619.

Kim, D. W., Park C. S. (2011) Diffuculties and limations in perfrmance simulation of a double skin façade with Energyplus. Energy and Buildings 43, 3635-3645.

Alexandra, P., Zhiqiang, Z. (2008) Numerical investigation on thermal performance and correlations of double skin facade with buoyanvy-driven airflow. Energy and building 40, 466-475.

Pasut, W., De Carli, M. (2012) Evaluation of Various CFD Modeling Strategies in Prediction Airflow and Temperature in a Naturally Ventilated Double Skin Façade. Applied Thermal Engineering 37, 267-274.

Flourentzou, F., Van der Mass, J., Roulet, C. A. (1998) Natural ventilation for passive cooling: measurement of discharge coefficients. Energy and Buildings 27, 283-292.

Department of Energy. (2018) EnergyPlus input/output reference.

Department of Energy. (2018) EnergyPlus engineering reference. 